КОНСТИТУЦІЯ УКРАЇНИ У ДІї

УДК 342.6

\author{
В. Мельник, \\ начальник Міжрегіонального управління Нацдержслужби \\ в Одеській, Миколаївській та Херсонські областях, \\ Автономній Республіці Крим та м. Севастополі
}

\title{
КОНСТИТУЦІЙНО-ПРАВОВІ ЗАСАДИ ІНСТИТУТУ ДЕРЖАВНОЇ СЛУЖБИ УКРАЇНИ
}

Україна перебуває сьогодні на шляху системних інституційних перетворень. Одним із основних напрямів іï реформ $€$ модернізація системи державної служби та формування нової кадрової політики, що виражається в активізації та професіоналізації державних службовців, нарощуванні й конструктивному використанні кадрового потенціалу. Структурні зміни державного управління та ефективного функціонування державних органів в Україні неможливі без належного законодавчого забезпечення. Тому так важливо створити в Україні механізм правового забезпечення управління державною службою, який дасть можливість запровадження якісних стандартів управління державною службою, що відповідають сучасному досвіду та кращим практикам управління розвинених країн.

Мета статті - виявити сучасні тенденціi процесу формування конституційно-правових засад державної служби. Актуальні проблеми правового забезпечення управління державною службою свого часу були й сьогодні $€$ предметом досліджень вітчизняних науковців у галузі адміністративного, трудового права та теоріï управління, а саме: В. Авер'янова, M. Александрова, С. Алексєєва, С. Ківалова, Б. Бегічева, Н. Болотіної, П. Жигалкіна, Р. Калюжного, Р. Кондратьєва, Н. Неумивайченка, П. Пилипенка, О. Скакун, Б. Стичинського,
В. Щербини, I. Арістова, О. Продаєвича, Ю. Кізлова, Л. Білої-Тіунової, О. Бандурка, Д. Бахрах, О. Кравченко, В. Погорілко, В. Толкованова й деяких інших учених. Незважаючи на наукові досягнення останніх років, ця проблематика в науковій літературі залишається недостатньо дослідженою та висвітленою, особливо це стосується питань конституційно-правових засад державотворення.

Конституційно-правовими засадами державної служби є законодавство України у сфері державного управління, яке базується на Конституції України та міжнародних правових нормах, ратифікованих в Україні. Законодавче забезпечення управління державною службою реалізується шляхом прийняття в установленому порядку уповноваженими суб'єктами нормативно-правових актів, що регулюють управління, організацію й функціонування державної служби, є ієрархічною системою, усі елементи якої є взаємопов'язаними та взаємодіючими [5]. Основою системи правового забезпечення управління державною службою $€$ Конституція України, яка визначає основні засади організації й діяльності державної служби як безпосередньо, так і через діяльність державних органів. Конституція України визначила державну службу як найважливіший інститут у справі розвитку української державності. Правовий аналіз поло- 
жень Конституції України дає можливість стверджувати, що вона містить положення, які прямо регулюють питання управління державною службою, а також ті, які прямо не визначають питання управління державною службою, проте впливають на встановлення принципів управління державною службою.

Проведене дослідження дає можливість зарахувати до першої групи норм норми, які прямо регулюють відносини державної служби: положення стаття 1, якою визначено, що Україна $€$ демократична, соціальна, правова держава; права і свободи людини та їх гарантії визначають зміст і спрямованість діяльності держави (ч. 2 ст. 3); в Україні визнається й діє принцип верховенства права (ч. 1 ст. 8); усі люди $€$ вільні й рівні у своїй гідності та правах (ст. 21); конституційні права і свободи гарантуються й не можуть бути скасовані, під час прийняття нових законів або внесення змін до чинних законів не допускається звуження змісту й обсягу наявних прав і свобод (ч. ч. 2-3 ст. 22); громадяни мають рівні конституційні права і свободи та є рівними перед законом (ч. 1 ст. 24). Конституція України встановлює принципи верховенства права (ст. 8), законності (ст. 19) і закріплює рівне право громадян доступу до державної служби. Також статтею 24 встановлено, що не може бути привілеїв чи обмежень за ознаками раси, кольору шкіри, політичних, релігійних та інших переконань, статі, етнічного й соціального походження, майнового стану, місця проживання, за мовними та іншими ознаками [1]. Усі згадані вище конституційні норми є базовими для правового забезпечення функціонування державної служби.

До другої групи конституційних норм можна зарахувати спеціальні норми-принципи, які визначають основи організації та діяльності органів державного управління. Розглядаючи ці норми, варто зазначити, що всі органи державної влади, виходячи зі своєї конституційної природи, «здійснюють свої повноваження у встановлених Конституцією межах і відповідно до законів України» (ч. 2 ст. $6 \mathrm{Koн}-$ ституції України) [1]. Вони «зобов'язані діяти лише на підставі, в межах повноважень та у спосіб, що передбачені Конституцією та законами України» (ч. 1 ст. 19 Конституції України). Виключно законами України визначаються організація й діяльність органів виконавчої влади, основи державної служби (п. 12 ч. 1 ст. 92). Вищим органом у системі органів виконавчої влади $є$ Кабінет Міністрів України, який, у свою чергу, є вищим органом у системі управління державною службою, який відповідальний перед Президентом України та підконтрольний і підзвітний Верховній Раді України в межах, передбачених у ст. ст. 85, 87 Конституції України. Саме Конституція України визначає основні повноваження державних органів щодо управління державною службою.

Розвиток конституційних засад державного управління та модернізація системи державної служби в Україні пов'язані з прийняттям низки нормативно-правових актів, що забезпечують правове регулювання управління державною службою. Провідне місце серед усіх нормативно-правових актів, покликаних упорядковувати механізм управління державною службою, займають закони. У сучасній науковій літературі з теорії держави і права зазначається, що закон - це нормативний юридичний акт вищого державного представницького органу або безпосередньо народу, який має найвищу юридичну силу, містить первинні правові норми країни [6, с. 82] і регулює певну систему правовідносин. Серед законодавчих актів, що визначають правові засади та регулюють правовідносини, пов'язані з управлінням системою державної служби, центральне місце посідає Закон України «Про державну службу», прийнятий 16 грудня 1993 р. за № 3723-XII. Варто зазначити, що цей Закон визначив організаційно-правову базу становлення держав- 
ної служби та ії кадрового потенціалу. Уперше в нашій країні зроблено спробу закріпити комплекс основних політико-правових засад функціонування державної служби. Новелою закону було визначення поняття державної служби, iï ознак, принципів державної служби, прав та обов'язків державних службовців, створення органу управління державною службою та його повноваження [2]. 3 моменту прийняття Закону Украіни «Про державну службу» № 3723-XII законодавча й нормативно-правова база отримала розвиток у шести законах України та понад 700 актах, зокрема указах і розпорядженнях Президента України, постановах Кабінету Міністрів України, наказах центрального органу 3 питань державної служби. Однак, окрім Закону України «Про державну службу», засади державної служби визначаються й іншими законами України. Варто звернути увагу на те, що текст базового закону містив відсильні норми на Кодекс законів про працю України, Закон України «Про засади запобігання і протидії корупції, Закон України «Про загальнообов'язкове державне пенсійне страхування», Закон України «Про місцеві державні адміністрації тощо. Можна стверджувати, що відповідні положення цих законодавчих актів також можуть розглядатися як такі, що визначають засади управління державною службою.

$\mathrm{У}$ період реформування модернізація інституту державної служби має здійснюватися за кількома напрямами шляхом реформування законодавчих та інституційних засад державної служби [7]. Одним із напрямів стало прийняття Указу Президента Украіни «Про заходи щодо впровадження Концепції адміністративної реформи в Україні» від 22 липня 1998 року, яким започатковано проведення широкомасштабної адміністративної реформи, визначено напрями формування нової системи державного управління як інструменту подолання кризи в Україні. Активізація процесу вдосконалення законодавчого забезпечення інсти- туту державної служби відбулася на початку 2000 р. 3 прийняттям Президентом України таких указів: «Про Координаційну раду 3 питань державної служби при Президентові України» та «Про Стратегію реформування державної служби в Україні».

Проте пострадянська модель модернізації інституту державної служби, легітимізована Законом України «Про державну службу» 1993 р., себе вичерпала й потребувала зміни філософіï діяльності основних суб'єктів державного управління. Саме тому в рамках проведення адміністративної реформи з урахуванням європейського вибору та європейської перспективи України владою розроблено і прийнято низку документів, які стосуються розвитку державної служби й певних аспектів державної кадрової політики. Серед основних правових документів потрібно виділити Стратегію державної кадрової політики на 2012-2020 рр., затверджену Указом Президента України від 1 лютого 2012 р. № 45/2012. Стратегія визначила мету, основні цілі, першочергові завдання, на реалізацію яких має бути спрямована державна кадрова політика, а також три етапи реалізації Стратегіï, відповідно до яких Кабінетом Міністрів України щороку розробляється план заходів щодо реалізації положень Стратегії державної кадрової політики на 2012-2020 pp.

Подальші комплексні системні зміни законодавства та послідовні кроки в імплементації законодавства до Європейських стандартів у процесі державного регулювання покладені в основу Стратегіі реформування державної служби та служби в органах місцевого самоврядування в Україні на період до 2017 р., яка схвалена Розпорядженням Кабінету Міністрів України від 18 березня 2015 р. № 227-р. Зазначена Стратегія визначила проблеми, що потребують розв'язання, мету, шляхи реалізації, індикатори реформи державної служби та служби в органах місцевого самоврядування. 


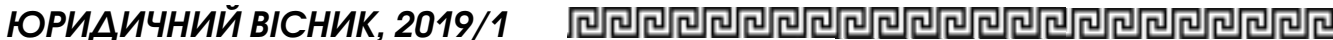

3 метою виконання зобов'язань, визначених Угодою про асоціацію між Україною і ЄС, розроблено Стратегію реформування державного управління України на 2016-2020 рр. та план заходів з ї реалізаціі, затверджені Розпорядженням Кабінету Міністрів України від 24 червня 2016 р. № 474-р. Основним напрямом реформування, визначеним у Стратегї, є модернізація управління державною службою й управління людськими ресурсами відповідно до європейських стандартів належного адміністрування, сформульованих у документі SIGMA «Принципи державного управління», а також належних практиках держав-членів EC i спрямованих на розв'язання проблем, що стоять перед системою державного управління в кадровому забезпечені державних органів. Координація роботи, проведення моніторингу та здійснення контролю за реалізацією Стратегії покладається на Національне агентство України з питань державної служби.

Прийняті владою стратегії реформування державного управління України зумовили серйозні законодавчі зміни в системі державної служби. Саме тому Національним агентством державної служби України за сприяння EC та активної участі громадськості розроблено новий Законопроект Украіни «Про державну службу», який отримав загалом позитивний висновок європейських експертів (Програми SIGMA) і став важливим кроком для розвитку системи державної служби й, зокрема, кадрового забезпечення державної служби в контексті політики сталого розвитку держави та суспільства. Ухвалений 10 грудня 2015 р. в другому читанні Верховною Радою України Закон України «Про державну службу» № 889-VIII (далі - Закон) [3], який із різних причин не один раз був пролонгований до вступу в дію, набрав чинності лише 1 січня 2016 р.

Метою Закону стало визначення стратегічних напрямів модернізації державної служби й удосконалення право- вого регулювання системи державної служби, ї елементів відповідно до європейських принципів ефективного врядування. Серед основних новацій Закону України «Про державну службу» варто відзначити зміну ролі керівників державних органів і працівників служб персоналу, що дадуть змогу змістити акценти 3 кадрового діловодства, яке нині домінує в кадрових службах, до управління персоналом. Однією з важливих новел Закону є принципово нова класифікація посад державної служби. Також у Законі застосовано компетентнісний підхід до оцінювання здатності державних службовців виконувати посадові обов'язки, визначені в посадовій інструкції, та встановлено новий підхід до навчання держслужбовців. Закон регламентує єдині процедури прийняття на державну службу та започатковує проведення відкритого, прозорого, об'єктивного конкурсу. Одним із важливих напрямів реформування державної служби, закладених у новому Законі, є подальше вдосконалення управління персоналом у системі державної служби. Уперше на законодавчому рівні (ст. 12 Закону) визначено систему управління державною службою, а базовим іiі елементом - службу управління персоналом.

Незважаючи на важливі досягнення Закону, він не здатний забезпечити комплексне реформування державної служби й потребує суттєвого вдосконалення та грунтовного підходу, що визнають багато науковців. Тому за час дії Закону до нього внесено більше ніж десять змін і поправок. Серед його принципових недоліків науковці називають звуження сфери державної служби; відсутність чітких професійних та інших вимог до зайняття посад державної служби; відсутність ефективних механізмів соціального захисту державних службовців, позбавлення їх професійних пенсій.

Характеризуючи юридичну сутність Закону України «Про державну службу в Україні», необхідно визначити, що він $є$ базовим норматив- 
но-правовим актом, який забезпечує функціонування інституту державної служби й посідає провідне місце серед усіх нормативно-правових актів, покликаних упорядковувати досліджувану групу відносин. У сучасній науковї літературі 3 теорії держави і права зазначається, що закон - це нормативний юридичний акт вищого державного представницького органу або безпосередньо народу, який має найвищу юридичну силу й містить первинні правові норми країни [8]. За своїм значенням закон є правовим актом первинного характеру. У законах містяться такі юридичні приписи, які становлять відправні начала інших підзаконних нормативно-правових актів у цій сфері. У нормативно-правовому забезпеченні управління державною службою, крім законів, беруть участь й інші нормативно-правові акти, які регулюють правові відносини у сфері функціонування державної служби (постанови, укази, рішення, розпорядження, накази тощо), проте вони мають підзаконний нормативний характер і можуть його розвивати, доповнювати та конкретизувати в одному випадку, а в іншому випадку містять стратегічні й концептуальні засади для підготовки та прийняття законів. Підзаконні акти забезпечують упровадження основних положень, закладених у нормах закону. Саме тому основні зусилля управлінців, законодавців і науковців спрямовані на розроблення нормативно-правових документів, які б забезпечили впровадження Закону України «Про державну службу» й удосконалення системи управління державної служби в Україні. 3 метою реалізації цього завдання в Національному агентстві України з питань державної служби створено робочі групи, до яких залучено фахівців профільних міністерств і відомств, експертів недержавних організацій, представників проектів технічної допомоги. У результаті плідної роботи розроблено і прийнято низку нормативно-правових актів у рамках забезпечення підготовки до впровадження Закону України «Про державну службу».

Правовий аналіз законодавства України у сфері державного управління дає можливість з'ясувати, яким чином створювалася система державної служби в Україні у 1993-2019 рр., і концептуалізувати досвід управління державною службою в період реформ.

На підставі проведеного аналізу можна зробити такі висновки. Конституція України визначає основні засади організації й функціонування державної служби як безпосередньо, так і через діяльність державних органів. Закон України «Про державну службу» є базовим нормативно-правовим актом, що забезпечує правове регулювання інституту державної служби в Україні. Інші закони України розвивають конституційні положення, визначають систему органів, які безпосередньо здійснюють повноваження 3 управління державною службою, їхній правовий статус і повноваження. Сучасний стан розвитку державної служби вимагає нормативно-правового вдосконалення та актуалізації положень законодавства. Зокрема, зміни архітектури державного управління потребуватимуть унесення змін до низки ключових нормативно-правових актів, а саме: Конституції України, законів України: «Про Регламент Верховної Ради України», «Про Кабінет Міністрів України», «Про центральні органи виконавчої влади», «Про державну службу», «Про місцеві державні адміністраціï» тощо. Правові акти, спрямовані на створення інституту державної служби України, потребують більшої чіткості, однозначності, визначеності й закінченості. Станом на сьогодні окремі положення цих законів не узгоджені між собою: є ознаки дублювання повноваження органів влади, а деякі положення окремих законів і підзаконних актів суперечать актам вищої юридичної сили. 


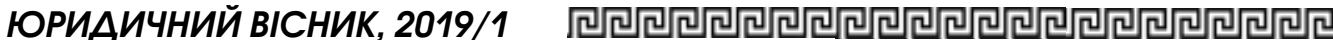

Ключові слова: Конституція Україн, інститут державної служби, нормативно-правові акти, державне управління, управління персоналом, нормативно-правове забезпечення.

У статті висвітлюеться процес формування конституційно-правових засад функціонування державної служби в Україні. Автор аналізуе конституиійно-правовий механізм забезпечення управління державною службою з огляду на євроінтеграційні процеси та модернізациію інституту державної служби.

B cmambe освещяается процесс формирования конституйонно-правовых основ функиионирования государственной службы Украины. Автор анализирует конституиионно-правовой механизм обеспечения управления государственной службой с учетом евроинтеграционных процессов и модернизации института государственной службы.

The article covers the formation of the constitutional and legal principles of the functioning of the civil service in Ukraine. The author analyzes the constitutional and legal mechanism of ensuring the management of the civil service in view of the European integration processes and the modernization of the civil service institute.

\section{Література}

1. Конституиія України: прийнята на n’ятій сесії Верховної Ради України 28 червня 1996 р. (зі змінами). URL: http:// zakon4.rada.gov.ua / laws / show / $254 \%$ D0\% BA/96-\% D0\% B2\% D1\% 80 .

2. Про державну службу : Закон України від 26 грудня 1993 р. (зі змінами та доповненнями). URL: http:// zakon4.rada.gov.ua/laws/show/3723-12.

3. Про державну службу : Закон Украінни віО 10 грудня 2015 р. № 889-VIII. URL: http: / / zakon2.rada.gov.ua/laws / show/889-19.

4. План заходів з реалізації Стратегіi реформування державного управління на 2016-2020 роки, затверджений Розпорядженням Кабінету Міністрів України віо 24 червня 2016 р. № 474-p. URL: http:// zakono.rada.gov.ua/laws/show /474-2016$\%$ D1\% 80 / paran268\#n268.

5. Ківалов С.В., Біла-Тіунова Л.Р. Публічна служба в Україні. URL: підручник. Одеса: Фенікс, 2009. 688 c.

6. Алексеев С.С. Проблемь теории права. Советское государство и право. 1983. № 4. С. 3-12.

7. Гончарук Н.Т., Прудиус Л.В. Модернізаиія державної служби та управління людськими ресурсами в Україні. Аспекти публічного управління. 2018. Т. 6. № 1-2. C. 42-51.

8. Арістов I.В. Нормативно-правове забезпечення державної служби в Украіні. Юридична наука і практика. 2011. № 1. C. $38-44$. 